\title{
Disregarding non-documentary conditions in letters of credit: Is it as easy as it appears to be?
}

\author{
Dr Jingbo Zhang*
}

\begin{abstract}
This paper discusses how to treat the problematic existence of a nondocumentary condition within a letter of credit that does not specify a required document to evidence its compliance. While the current Uniform Customs and Practice for Documentary Credits (UCP) simply direct banks to disregard such non-documentary conditions in the process of document examination, neither consistent interpretation has been provided to this rule, nor a precise scope of non-documentary conditions given for the past two decades. Through analysing judicial applications of the UCP disregard rule under the common law system, this paper submits that the UCP disregard rule does not achieve its desired effect to eradicate non-documentary conditions. It is further argued that the disregard approach frustrates the commercial parties' expectations and does not work as an effective method to resolve the non-documentary problem for banks. An alternative is submitted for consideration herein, based on the "evidence" approach adopted by English common law which effectively turns the non-documentary condition into documentary proof, such that it can meet the commercial expectations of all parties while keeping the independent feature of

letters of credit intact.
\end{abstract}

\section{INTRODUCTION}

The letter of credit, an instrument traditionally facilitating and financing international commercial transactions, alleviates risk borne by commercial parties by providing an autonomous and predictable system for payment. ${ }^{1}$ A distinguishable feature of letters of credit, as well as of other varieties of banks' independent payment undertakings, lies in that

\footnotetext{
* Lecturer in Commercial and Maritime Law, University of Southampton. The author is very grateful to Professor James Davey and Professor Paul Todd, University of Southampton, for their constructive comments on an early draft. Special thanks to Distinguished Professor John Dolan, Wayne State University, for his help of collecting the US resources, and to the anonymous reviewer for providing useful suggestions to improve this paper. All errors and omissions are my own.

1. According to the International Chamber of Commerce 10th Annual Global Survey 2018, the value of traditional trade finance provided by respondents was over US\$4.6 trillion in 2017. Among the portfolio of traditional trade finance, commercial letters of credit counted to $49 \%$ and standby letters of credit took up to $11 \%$. The survey also showed that $72 \%$ of banks based in Africa preferred commercial letters of credit and banks in the Asia Pacific region issued more than three million letters of credit in 2017. See International Chamber of Commerce, Global Trade-Securing Future Growth (ICC Publication No.890E, Paris, 2018),
} 
their operation is based on documents and documents alone. Non-documentary conditions, which are obstinately listed in a letter of credit without stipulating the documents to be presented in compliance therewith, unfortunately muddy the waters of documentary credit transactions by adding extraneous uncertainties to the system. The current major sources on governing letters of credit, including the Uniform Customs and Practice for Documentary Credits (UCP) drafted by the International Chamber of Commerce (ICC), seemingly instruct the banks to "treat such a non-documentary condition as not stated and disregard it". ${ }^{2}$ The banks may be tempted to follow this conceptually simplified "disregard rule" and believe that they are immune from any liability, and that accordingly they can still turn to their customers for reimbursement regardless of whether or not the nondocumentary conditions are satisfied.

In reality, however, the disregard approach is not as hassle free for the banks as they would desire. Judicial courts worldwide, as well as the ICC Banking Commission, have continued to face disputes over recurrent non-documentary conditions for the past 25 years. For instance, an argument as to whether the non-documentary condition "Entire materials will be dispatched after final inspection by Mr Sanjay Hazra" should affect the bank's payment was raised in the recent Hong Kong Huihuang Industrial v Allahabad Bank. ${ }^{3}$ An enquiry on the recognition of a non-documentary condition "In case of delay ... beneficiary should attach a credit note ..." was also discussed in a recent ICC Banking Commission annual meeting. ${ }^{4}$ Apart from these continuing disputes, the disregard rule has also been repeatedly nominated as a problematic provision to be clarified in the next UCP revision, as its interpretation is far from being settled. ${ }^{5}$

It is astonishing to find out at the outset of this paper that the UCP have neither conferred on their disregard rule an overriding position over the express conditions in the documentary credit, nor clearly defined the scope of non-documentary conditions. Through examining the judicial application of the disregard rule in the common law system, especially under English law and the US Uniform Commercial Code (UCC), ${ }^{6}$ this paper contends that the protection provided by the disregard rule is merely a paper shield for unwary parties. This contention is based on the following two arguments. First, no courts can easily ignore the contractually designed express terms which in most instances truly reflect the business intentions. Secondly, a bank is not in a position to

https://iccwbo.org/publication/global-survey-2018-securing-future-growth/, 41-74. Even in the Americas, where the proportion of traditional trade finance is somewhat lower than other parts of the world, totals for the top 600 US banks on letters of credit activities in the first quarter of 2018 were still US $\$ 382$ billion. See quarterly figures reported in "Statistics: US Banks" (2018) 22(7) Documentary Credit World 48, 58.

2. See post, text to fn. 18 .

3. (2016) WL 1664008 (CA); [2016] HKEC 2328. The issue was left undecided by the courts, as the parties were more or less agreed that the inspection certificate was available for the purpose of honouring the letter of credit at the time.

4. Query TA.878rev in International Chamber of Commerce, Final Opinions of the Banking Commission: Document 470/1274rev (London, November 2017).

5. Anna-Mari Antoniou, "New Rules for Letters of Credit: Time to update the UCP 600" [2017] JIBLR 128, 134; Nesarul Hoque, "An Early Expectation of UCP700" (2015) 19 (8) Documentary Credit World 22, 24.

6. The United States example is chosen in this paper because of its established trade statute, the Uniform Commercial Code (hereafter "UCC"), of which Art.5 exclusively deals with letters of credit. The original UCC Art.5 was promulgated in 1962 and the current revision was made in 1995. This paper only deals with the 1995 version and refers to it as "UCC Revised Article 5". The UCC Revised Art.5-108(g), contains a comparable "disregard" provision against non-documentary conditions. 
assess, or even capable of assessing, whether a non-documentary condition is central or fundamental to the operation of a letter of credit. The paper further suggests that the disregard rule neither provides banks the operational ease as envisaged, nor fits in with the expectations of commercial parties in international trade transactions, particularly in terms of standby letters of credit.

After questioning whether the disregard rule functions as an effective solution to treat the existence of non-documentary conditions, an alternative approach to handle the problem has been tentatively sought at the end of this paper. In essence, what the banks really need is a piece of paper to convert the non-documentary conditions into documentary evidence. To this extent, the author favours the "calling for evidence" approach adopted in the leading English case Banque de l'Indochine et de Suez SA v J H Rayner (Mincing Lane) $L t d^{\top}$ and indorses that it is an appropriate pathway to solve the conflicts that arise from non-documentary conditions. Although conceding that, other than by eradication at the outset, there is no magic bullet for resolving the issue of non-documentary conditions in letters of credit, this paper advocates that the "calling for evidence" approach is best suited to meeting the commercial expectations of the parties while simultaneously maintaining the integrity of the documentary credit mechanism.

\section{IDENTIFICATION OF NON-DOCUMENTARY CONDITIONS AND THE UCP DEFICIENCIES}

It is well known that a "documentary credit" stands for an independent payment undertaking made by an issuing bank to the beneficiary at the request of the applicant. ${ }^{9}$ The idea is that, as long as the beneficiary presents the complying documents specified in a documentary credit, the bank will be obliged to provide a specified payment. The $\mathrm{UCP},{ }^{10}$ as a set of international standard banking practice rather than rules of law, have been widely accepted and applied to regulate letters of credit transactions. Their binding force is deemed to be given through contractual incorporation. The current UCP 600 Art.1 stipulates that they "are rules that apply to any documentary credit ('credit') (including, to the extent to which they may be applicable, any standby letter of credit) when the text of the credit expressly indicates that it is subject to these rules". ${ }^{11}$ Although commercial and

7. [1983] 1 Lloyd's Rep 228; [1983] QB 711.

8. The term "documentary credit" in this paper is interchangeable with "letter of credit", which widely covers both traditional letter of credit (also referred as "commercial letter of credit") and "standby letter of credit".

9. See UCP 600, Art.2. A similar definition of letter of credit is stipulated in the UCC Revised Art.5-102(a) (10). The principle of independence is emphasised in UCP 600 Arts 4 \& 5 and the UCC Revised Arts 5-103(d) and 5-108(f).

10. The UCP were revised in 1951, 1962, 1974 (UCP 290), 1983 (UCP 400), 1993 (UCP 500) and most recently in 2007 (UCP 600).

11. The name "standby letter of credit" was generated in the US to secure the performance of contractual obligations. It is functionally similar to a performance bond in the UK and the names have been used interchangeably. This paper only focuses on letters of credit rather than other types of independent guarantees, so that the referred terminology is confined to the issuing bank, the applicant and the beneficiary. Standby credits were brought into the UCP from the 1983 Revision (UCP 400). The words "to the extent" in the UCP expressly acknowledge that some UCP provisions may not apply to standby credits, but no individual provisions have been officially identified. 
standby credits are distinctive in business use, ${ }^{12}$ they share the same legal feature of being an "abstract payment undertaking", ${ }^{13}$ which in essence, means that they are independent of the underlying transactions and documentary in character. ${ }^{14}$

As a type of condition stated in the credit but without specifying a required document to evidence its compliance, the non-documentary condition is clearly repugnant to the independence principle, because it breaks the first rule of a letter of credit transaction, namely, that the parties are dealing in documents, not facts..$^{15}$ In order to eradicate wrong banking practice and maintain system integrity, UCP 500 initiated the "disregard rule" to strike out the existence of non-documentary conditions, and this approach has been followed by the major rules on banks' independent payment undertakings, ${ }^{16}$ including UCP 600 and the UCC Revised Art.5. ${ }^{17}$ The disregard rule in UCP 600 states that, "if a credit contains a condition without stipulating the document to indicate compliance with the condition, banks will deem such conditions as not stated and will disregard it". ${ }^{18}$ At the outset, it is crucial to identify what constitutes a "non-documentary condition"19 and trace back the UCP timeline to examine how this rule has been interpreted, before questioning judicial and practical applications of the rule.

\section{A. What constitutes a non-documentary condition?}

\section{UCP's problematic interpretation and evolution}

Although the UCP repetitively use the word "condition" in their provisions, it is surprising to observe that the UCP have never made an effort to define or explain what constitutes a "condition". The only reference drawing from the relevant ICC publications

12. The primary function of a commercial letter of credit is to provide payment for the performed contract, while a standby credit aims to secure an indemnity for failure to perform the contract.

13. R Goode, "Abstract Payment Undertakings and the Rules of the International Chamber of Commerce" (1994) 39 St Louis ULJ 725, 726-727.

14. The English Court of Appeal has recently underpinned the independent nature of standby letter of credit in National Infrastructure Development Co Ltd v Banco Santander SA [2017] EWCA Civ 27; [2017] 1 Lloyd's Rep 361. This is in a stark contrast with the bank's accessory undertakings in a commercial guarantee, under which the bank as a guarantor enjoys the defences available to the principal debtor in the underlying contract to set against the beneficiary's claims.

15. See Banque de l'Indochine et de Suez SA v JH Rayner (Mincing Lane) Ltd [1983] 1 Lloyd's Rep 228, 230-231; [1983] QB 711, 728 (Sir John Donaldson MR).

16. Apart from the UCP, the main sets of rules for bank's independent payment undertakings include: International Standby Practices 1998 (ICC Publication No.590) (hereafter "ISP 98"), which are used primarily with standby letters of credit; Uniform Rules for Demand Guarantees 2010 (ICC Publication No.758) (hereafter "URDG 758"), which apply to demand guarantees; and the UN Convention on Independent Guarantees and Standby Letters of Credit 1995 (hereafter "UN Convention"), which are intended for use with all types of independent guarantees. However, none of them has achieved the high level of usage and acceptability which the UCP did.

17. The disregard rule or its analogue can be found in UCP 500, Art.13(c), UCP 600, Art.14(h), UCC Revised Art.5-108(g), ISP 98, rule 4.11 and URDG 758, Art.7. This paper limits its ambit to the UCP and the UCC, although references to other sets of rules will be added when necessary.

18. See UCP 600, Art.14(h), which is identical to its predecessor in UCP 500, Art.13(c).

19. The term "non-documentary condition" was first used in the "Report of the ABA Task Force on the Revision of UCC Article 5 (Letters of Credit)" published in "An Examination of U.C.C. Article 5 (Letter of Credit)" (1990) 45 Bus Law 1521 (hereafter “Task Force Report”), 1546. Neither UCP 500 nor UCP 600 include this term in their provisions, but it has been officially recognised by the ICC in the International Standard Banking Practice (ICC Publication No.745, 2013 revision) (hereafter “ISBP 745”), A26. 
was to emphasise the difference between "conditions" and "terms", which pointed out that the former are future and uncertain events as distinguished from the latter, which are certain to take place. ${ }^{20}$ For instance, the date of issuance or expiration should be regarded as a term rather than a condition, because its occurrence is certain to happen. The same would apply to the mode of performance, such as where and how the documents are to be presented. ${ }^{21}$ Therefore, not every term listed in the letter of credit is qualified to be a condition, as it must be "a future and uncertain event on which the obligation to pay is dependent". ${ }^{22}$

It is not uncommon for letters of credit to contain conditions that are physically separate from the documents in which they are to be reflected. Usually, these conditions can be related to one of the required documents by a contextual reading of the terms of the credit. The ICC Banking Commission recognised such a practice in UCP 500 Position Paper No.3 and distinguished a condition "which can be clearly linked to a document stipulated in that documentary credit" ${ }^{23}$ from a free-standing non-documentary condition within the ambit of the disregard rule. ${ }^{24}$ For example, if a letter of credit states "German origin" as a special condition but stipulates a certificate of origin in the same credit, then "German origin" is not a non-documentary condition, as the certificate of origin would have to evidence it. ${ }^{25}$

Nevertheless, most of the cases are far from being as straightforward as above. ${ }^{26}$ What would be the result if there was no required certificate of origin in the above example, but a certificate of inspection tendered with the statement that goods were of French origin? ${ }^{27}$ In one case, the ICC Banking Commission refused to consider the term of "shipment to be by seafreight vessel sailing to Mombasa Port via Suez" stated in the letter of credit "special instructions" as a non-documentary condition, since the term could be related to the stipulated bill of lading. ${ }^{28}$ However, in another case, the Banking Commission claimed the term "demurrage for goods shipped prior to L/C issuance are for beneficiary's account" to be non-documentary, although it could possibly be argued that this term would link with the statement in the bill of lading and commercial invoice. ${ }^{29}$

Since there is no guideline on assessing "clearly linked", "it has been suggested that the Position Paper's linkage test suffered from a regrettable vagueness that served only

20. Charles del Busto (ed), Documentary Credits: UCP 500 \& 400 Compared (ICC Publication No.511, 1993), 42. The same point was reflected in the Task Force Report, 1549, and the UCC Revised Art 5-108 Official Comment 9, as well as ISP 98, Art.4.11.

21. These examples were given in the Task Force Report, 1549; the UCC Revised Art.5-108 Official Comment 9 and ISP 98, Art.4.11, but a specific reference has not been made in the ICC publications.

22. Task Force Report, 1549.

23. Emphasis added.

24. ICC Banking Commission, "Position Papers No 1, 2, 3, 4 on UCP 500 Uniform Customs and Practice for Documentary Credits" (1 September 1994), Position Paper No.3.

25. This example was given ibid, Position Paper No.3.

26. A few complicated scenarios are discussed in Dennis Noah, "The Case of the 'Oily' Non-Documentary Condition" (2001) 5(6) Documentary Credit World 35.

27. In this circumstance, the special condition "German origin" can arguably be disregarded under UCP 500 and not be a basis for refusal of a presentation.

28. Gary Collyer and Ron Katz (eds), ICC Banking Commission Collected Opinions 1995-2001 (ICC Publication No.632, 2002), R212.

29. Ibid, R326. 
to introduce uncertainty". ${ }^{30}$ In addition, UCP 600, which maintain the same disregard provision, state that the Position Paper No.3 under UCP $500^{31}$ would no longer be applicable to interpret non-documentary conditions. ${ }^{32}$ Therefore, "non-documentary condition" in UCP 600, Art.14(h) appears to be construed in a more literal fashion, i.e. every condition that fails to stipulate a corresponding document to evidence its compliance will be disregarded, whether or not its satisfaction can be determined through linking with the presented documents. ${ }^{33}$ As a result, the bank was entitled to disregard a special requirement on the place of delivery, even though a "forwarding agent's goods receipt" was called for in the credit which could clearly link with the fact and evidence the performance. ${ }^{34}$

\section{UCP's drawback compared with other uniform rules}

In contrast with UCP 600, which simply describe a non-documentary condition as "a condition without stipulating the document to indicate its compliance", the other sets of rules in relation to a bank's independent undertakings have adopted a more refined view in defining non-documentary conditions. For example, being a non-documentary condition under UCC Revised Art.5 would require an issuer to decide or investigate extrinsic facts, rather than just "consulting the clock, the calendar, the relevant law and practice, or its own general knowledge of documentation or transactions of the type underlying a particular letter of credit". 35

The International Standby Practices 1998 ("ISP 98") 36 use slightly different wording but aim to achieve a similar effect. ISP 98 identify that conditions can only become nondocumentary if no corresponding document is required and "if their fulfilment cannot be determined by the issuer from the issuer's own records or within the issuer's normal operations". ${ }^{37}$ ISP 98 further direct an issuing bank to check its own account for the monetary transaction and refer to a published index such as published interest rates. ${ }^{38}$ This

30. Michael Bridge (ed), Benjamin's Sale of Goods, 10th edn (Sweet and Maxwell, 2017) (hereafter "Benjamin") [23.110].

31. See supra, fn.24.

32. UCP 600, Introduction.

33. Gary Collyer, Commentary on UCP 600: Article by Article Analysis by the UCP 600 Drafting Group (ICC Publication No.680, 2007) 66. See also Benjamin, [23.110]; Patric McGonigal, "UCP 600_Key Changes", in James E Byrne (ed), 2009 Annual Review of International Banking Law \& Practice (IIBLP 2009) 270.

34. Gary Collyer and Ron Katz (eds), ICC Banking Commission Opinions 2005-2008 (ICC Publication No.697, 2008), R640. It should be noted that a forwarding agent's goods receipt is not a transport document covered by UCP 600, Arts 19-25, so it is not obliged to evidence shipment and delivery ports.

35. UCC Revised Art 5-108(g), Official Comment 9. See JP Morgan Trust Co v US Bank (2006) 446 F. Supp. 2d 956 (E.D. Wis.), where the court held that the issuing bank was not in violation of the independent principle when the fulfilment of a condition in the documentary credit was assessed by looking at the bank's own records.

36. See supra, fn.16.

37. See ISP 98, Art 4.11(b). Examples that a condition can be determined by the issuer from its own record or operations are illustrated in ISP 98, Art 4.11(c). A similar position is adopted in the Explanatory Note by the UNCITRAL Secretariat on the United Nations Convention on Independent Guarantees and Stand-by Letters of Credit www.uncitral.org/pdf/english/texts/payments/guarantees/guarantees.pdf, [19], which excludes conditions that "would relate to acts or events within the sphere of operations of the issuer" from the scope of non-documentary conditions.

38. See ISP 98, Art.4.11(c). See also James E Byrne, The Official Commentary on the International Standby Practices (IIBLP 1998), 169, in which Professor Byrne interpreted "commodity prices" as a part of published 
proposition is supported by the argument that these publications are well known and of public record as well as commonly and readily available, which are deemed to be within the issuer's operational purview. ${ }^{39}$

The ICC Banking Commission is clearly moved by the trend to refine the scope of non-documentary conditions, because the latest Uniform Rules for Demand Guarantees ("URDG") ${ }^{40}$ confine the scope of non-documentary conditions to conditions of which fulfilment "cannot be determined from the guarantor's own records or from an index specified in the guarantee". ${ }^{41}$ Nevertheless, UCP 600 have been kept intact, as has the latest International Standard Banking Practice 745 (ISBP 745). ${ }^{42}$ There cannot be other ways of explaining the difference between the UCP and the URDG on this point, except for an omission, given that the ICC Banking Commission is eager to equalise the operational features of demand guarantees with those in documentary credits, especially in terms of independence principle.

\section{B. A flawed restriction to the disregard rule under UCP 600}

Within one year of launching UCP 600, the ICC Banking Commission held in Query TA.644 rev $^{43}$ that a condition referring to "latest shipment date" without stipulating a required document to indicate its compliance would be deemed a non-documentary condition and disregarded under Art.14(h); however, should the beneficiary elect to insert the data regarding the "latest shipment date" on any other stipulated document, it must ensure that the data would not conflict with those in the non-documentary condition. The conclusion further drawn by the ICC was that, since a non-documentary condition remains a part of the credit, "Article 14(h) is not absolute and is qualified by the content of Article 14(d)" ${ }^{44}$ This conclusion has subsequently been added into the latest ISBP 745, which interprets the UCP 600 disregard rule as follows: "When a credit contains a condition without stipulating a document to indicate compliance therewith ("nondocumentary condition'), compliance with such condition need not be evidenced on any

index, which indicated that the floating price clause in the letter of credit would not belong to non-documentary conditions. The author respectfully doubts this broad interpretation, as this will direct a bank to check the mercantile market which is arguably beyond its normal purview.

39. Byrne, supra, fn.38, 169. Different from the UCP, ISP 98 also widely cover non-documentary conditions at the stage of credit issuance, amendment and termination. These stages are equally important as to the stage of document examination, but they are beyond the scope of this paper. Detailed discussion can be found in Ningning Zhang, "The Effect of Non-documentary Conditions in Documentary Credits" (2010) 14(10) Documentary Credit World 21; Nesarul Hoque, "Is There Any Need for Expansion of Scope of Documentary Condition under UCP?" [2014] Trade Services Update, Oct-Dec, 9.

40. See supra, fn.16.

41. URDG 758, Art.7.

42. See supra, fn.19.

43. Gary Collyer and Ron Katz (eds), ICC Banking Commission Opinions 2005-2008 (ICC Publication No.697, 2008), R631.

44. The conclusion was followed by Query TA.689 in Gary Collyer and Ron Katz (eds), ICC Banking Commission Opinions 2009-2011 (ICC Publication No.732, 2012), R743. UCP 600, Art.14(d) states: "Data in a document, when read in context with the credit, the document itself and international standard banking practice, need not be identical to, but must not conflict with, data in that document, any other stipulated document or the credit." 
stipulated document. However, data contained in a stipulated document are not to be in conflict with the non-documentary condition." ${ }^{45}$

Clearly, the ICC Banking Commission intended to eschew the controversial concept of linkage which was used under UCP 500 for refining the scope of non-documentary conditions and, instead, it focused on qualifying the application of the disregard rule. Nevertheless, there is no sound basis in UCP 600 to support the paramount status of the Art.14(d) "no conflict" rule conferred by this interpretation. As both Art.14(h) and Art.14(d) are standard terms for document examination, a general incorporation will give them the same legal position in the contract. ${ }^{46}$

Another issue caused by placing an overriding status of the "no conflict" rule in Art.14(d) is the danger of excessive examination. From a practical point of view, in order to be sure that there are no conflict data between the non-documentary condition and the stipulated documents, should the bank scrutinise all the terms and conditions contained in each document, even those small print on the back of transport documents? ${ }^{47}$ Should the bank check the data contained in a superfluous document which was supposed to be disregarded by the bank in Art.14(g) ${ }^{48}$ Such an application is clearly repugnant to the intention of bankers and will inevitably undermine commercial efficiency. ${ }^{49}$

The author undoubtedly questions the relationship between Art.14(d) and Art.14(h) created by the ICC Banking Commission, but does not intend to suggest an opposite proposition, ie, to mandate a bank to turn a blind eye towards non-documentary conditions and accept a documentary presentation that contradicts the terms of the credit. What is obviously revealed here is the ICC Banking Commission's intention to narrow down the scope of non-documentary conditions that have currently fallen into the purview of the disregard rule. ${ }^{50}$ However, in the author's view, the problem has been tackled from an inappropriate direction, with a legally unsound basis. The so called "non-documentary conditions" restricted by the "no conflict" interpretation are in fact not genuine non-documentary conditions intended to be covered by the UCP, since their fulfilment can be self-evidently determined by reviewing the stipulated documents in the bank's own hands, without the need to investigate extrinsic facts outside the bank's

45. ISBP 745, A26. An equivalent approach applied to specific documents can be found in ISBP 745, L7, M4, N4 and Q7.

46. See James E Byrne, UCP 600: An Analytical Commentary (IIBLP, 2010), 653, which argues "the approach represented in the Opinion amounts to amendment of UCP 600 by stealth and should be disregarded by courts in interpreting the rule".

47. $C f$ UCP 600 Art.20(a)(v), which specifically exempts banks from examining terms and conditions of a bill of lading.

48. UCP 600, Art.14(g) stipulates that "a document presented but not required by the credit will be disregarded and may be returned to the presenter". A similar doubt is raised in "Extraneous Documents Disregarded? Answer Should Be Obvious, But Might Not Be" (2016) 20(8) Documentary Credit World 11, 12.

49. The same concern is shared in Byrne, supra, fn.46, 653.

50. Although UCP 600 abandon the linkage test under UCP 500 for refining the scope of non-documentary conditions, this does not necessarily mean that UCP 600 intentionally adopt a literal meaning to interpret nondocumentary conditions covered by the disregard rule. On the contrary, the "no conflict" restriction reflects the ICC's restraining view of allowing all the so called "non-documentary conditions" stated in the credit to be totally ignored. The difference between the linkage test under UCP 500 and the restrictive view under UCP 600 lies in that banks under UCP 600 are not obliged painstakingly to link the non-documentary conditions with the presented documents. 
operational purview. The logical explanation for rejecting the given presentation in the Query TA.644 rev is not a conceivable conflict between the so called "non-documentary condition" and the data shown on a presented document, but that, when the "latest shipment date" appears on a presented document within the bank's operational purview, it ceases to be a non-documentary condition unwittingly. ${ }^{51}$

\section{Non-documentary conditions in the spotlight}

The crux of the above problems lies in that the UCP have been "introducing an abstraction into rules of practice without providing any specification as to its contours". ${ }^{52}$ The abstraction, "non-documentary condition", remains the first issue to be ascertained by banks whenever they ignite the UCP disregard rule. It is submitted that the UCP have omitted exclusion of conditions that a bank can readily ascertain in the course of its ordinary operation from the scope of non-documentary conditions. A condition should not be regarded as non-documentary, if its compliance can be evidenced from any document expressly required anywhere in the letter of credit. ${ }^{53}$ This paper therefore focuses only on addressing the truly "objectionable" non-documentary conditions, namely the existence of which are incompatible with the documentary nature of a bank's independent undertaking. As a truly objectionable non-documentary condition, its fulfilment must be determined from drawing extrinsic facts or assessing the occurrence of an event outside the bank's operational purview, ${ }^{54}$ whether such a condition is derived from careless and clumsy drafting or unartful attempts to assure performance of certain behaviour.

Similar to the UCP, all the major rules on letters of credit disapprove of the inclusion of non-documentary terms, but the question as to what should be done when they arise in the process of document examination by banks, or, by courts in a letter of credit litigation, remains problematic. As we shall see below, various courts have to some extent restricted or even abandoned the disregard approach, either by interpreting the letter of credit contracts, or by judicial creation of a "fundamental exception".

\section{SPECULATIVE APPLICATION OF THE DISREGARD RULE UNDER ENGLISH LAW}

As rules of standard banking practice, the UCP are generally given the force of law by contractual incorporation in the UK and most other common law countries. Consistent with their contractual status, the UCP provisions fall to be construed in accordance with the normal approach for commercial contracts, although regard must be given to

51. Byrne, supra, fn.46, 655.

52. Ibid, 650 .

53. In this regard, the author disagrees with the trial court judgment in United Overseas Bank (Malaysia) Bhd v Indian Bank (9 Jan 2013) Unreported (Sing HC), which treated the additional requirement of inspection certificate unlisted in the SWIFT "Required Documents" field as non-documentary conditions and disregarded it.

54. This view is in accordance with the position taken by the UCC Revised Art.5, the UN Convention, ISP 98 and URDG 758 as discussed. See ante, text to fnn 35-42. 
their international character. ${ }^{55}$ In general, the UCP and common law do not conflict, but occasionally the courts must work out a method for resolving situations when they bump into one another. ${ }^{56}$

Once incorporated, the UCP rules are binding on all the contractual parties unless "expressly modified or excluded by the credit". ${ }^{57}$ Clearly, an explicit exclusion or amendment of the UCP disregard rule in a letter of credit must be respected; however, the issue is whether, without such a variation, the existence of a non-documentary condition could displace the application of the UCP disregard rule.

According to the well-known principle in construction of contracts, where there is a conflict between an express term of the contract and a standard term incorporated by reference, the express term would be given preference on the ground that it is more likely to manifest the intention of the parties in the transaction. ${ }^{58}$ Following this spirit, the bespoke non-documentary condition in the documentary credit should override any inconsistent provisions in the UCP, including the disregard rule.

Nevertheless, tension arises in that the English court may desire to uphold the UCP regime and require the clearest wording to evidence the parties' intention of departure, given the worldwide adoption of the UCP and the benefits afforded by the uniformity of documentary credit practice. ${ }^{59}$ In Forestal Mimosa Ltd v Oriental Credit Ltd ${ }^{60}$ Sir John Megaw in the Court of Appeal held that the UCP would be overridden only in the event of an "irreconcilable inconsistency", and therefore the term in the credit "available by acceptance of [the beneficiary's] drafts ... drawn on [the applicant]" could not justify any implied exclusion of the confirming bank's independent payment undertaking under the UCP. ${ }^{61}$

Despite the tone set by Forestal Mimosa in the English court, the first case directly dealing with the conflict between a non-documentary condition and the UCP disregard rule was Kumagai-Zenecon Construction Pte Ltd $v$ Arab Bank Plc, ${ }^{62}$ a leading Singaporean case, which followed the English rules of construction. In this case, cl.2

55. See Bankers Trust Co v State Bank of India [1991] 2 Lloyd's Rep 443, 456 and Taurus Petroleum Ltd v State Oil Marketing Co of the Ministry of Oil, Republic of Iraq [2017] UKSC 64; [2018] 1 Lloyd's Rep 295; [2017] 3 WLR 1170, [61] (Lord Sumption).

56. John F Dolan, The Law of Letters of Credit: Commercial and Standby Credits, 4th edn (A.S. Pratt \& Sons, 2007) (hereafter "Dolan"), [4.01].

57. UCP 600, Art.1.

58. Glynn v Margetson [1893] AC 351, 358; Homburg Houtimport BV v Agrosin Private Ltd (The Starsin) [2003] UKHL 12; [2003] 1 Lloyd's Rep 571; [2004] 1 AC 715, [11]. See HG Beale (Gen ed), Chitty on Contracts, 32nd edn (Sweet \& Maxwell, 2015) (hereafter "Chitty"), [13.082]; Kim Lewison, The Interpretation of Contracts, 2nd edn (Sweet \& Maxwell, 2015) (hereafter "Lewison"), [7.04] and [9.10]. This principle was also applied in both Singaporean cases Kumagai-Zenecon Construction Pte Ltd v Arab Bank Plc [1997] SGHC 31, affd [1997] SGCA 41 and Korea Exchange Bank v Standard Chartered Bank [2006] 1 SLR 565. See post, text to fnn 62-67.

59. See Fortis Bank SA/NV v Indian Overseas Bank [2011] EWCA Civ 58; [2011] 2 Lloyd's Rep 33, [29], where Thomas LJ held that the court must recognise the international nature of the UCP and approach its construction in that spirit. See also Benjamin, [23.008]; Ali Malek and David Quest, Jack: Documentary Credits, 4th edn (Tottel, 2009) (hereafter "Jack"), [8.24].

60. [1986] 1 Lloyd's Rep 329; [1986] 1 WLR 631.

61. Ibid, 639. Sir John Megaw refused to interpret an express term into an incompatible meaning against the commercial understanding of a documentary credit, because the term at issue would open to the applicant to "render the bank's obligation to the [beneficiary] under the credit a wholly useless obligation".

62. [1997] SGHC 31; [1997] 1 SLR (R) 277; affd [1997] SGCA 41; [1997] 2 SLR (R) 1020. 
of the standby letter of credit (incorporating UCP 500) required the bank to pay the liquidators the sum payable by Low (the buyer) pursuant to his obligations to KIP (the seller) as determined by the courts' judgments. The documents specified in the credit included copies of courts' judgments and the accompanied demand. However, instead of assigning a precise figure, the judgments only indicated that Low's obligation was to pay the higher of the purchase price and the fair price of the relevant shares. Since the liquidators did not furnish the bank with a copy of the valuation report to justify the amount of demand, the bank refused to pay. The central issue of this case was therefore whether the bank should treat cl.2 of the credit as a non-documentary condition and ignore it under the disregard rule stipulated in UCP 500, Art.13(c).

The Singaporean High Court supported the bank's rejection with a purposive view. ${ }^{63}$ Judith Prakash J explained: ${ }^{64}$

"Whilst I recognised the desirability of upholding the provisions of UCP-500 in general, it appeared to me that in this instance the circumstances were such that the credit could only be operated if the non-documentary conditions ie the ascertainment of the fact and quantum of Low's obligation were satisfied. Otherwise the credit did not make sense since the implication was that any amount within the maximum limit of the credit could have been demanded irrespective of the effect of the two judgments. I therefore found that in this case Art $13 \mathrm{c}$ had been excluded by implication because of the express wording of $\mathrm{cl} 2$ of the credit."

The Singaporean Court of Appeal fully upheld the decision made by the High Court. It further dismissed the appellant's reliance on the Forestal Mimosa case and emphasised that the operation of the credit in the present case gave rise to "irreconcilable inconsistency" between the express terms of cl.2 and the UCP provisions. By reason of this inconsistency, both the disregard rule in UCP 500, Art.13(c) and the second paragraph in Art.13(a) (which directed the bank not to examine documents outside the stipulation of the credit) were implicitly excluded, and the liquidators should have tendered appropriate document proof in support of their demand.

The same approach was adopted in a subsequent case under UCP 500, Korea Exchange Bank $v$ Standard Chartered Bank.$^{65}$ In this case, the issuing bank contended that the "price escalation clause" in the commercial credit for the trade in gas oil was a non-documentary condition, so that the term should be disregarded at the payment to the negotiating bank. The Singaporean High Court rejected this argument and gave force to the express term in the credit by stating that: ${ }^{66}$

"The quoted words ["unless otherwise expressly stipulated in the Credit" in Article 1] have not been interpreted so stringently as to mean that only an express exclusion of any particular provision of UCP 500 will have effect. It is enough if an express provision in the LC stipulates a requirement which is clearly at odds with a provision in UCP 500 in circumstances where an implication may be

63. The purposive construction was described by Lord Halsbury in Glynn v Margetson \& Co [1893] AC 351, 357: "Looking at the whole of the instrument, and seeing what one must regard ... as its main purpose, one must reject words, indeed whole provisions, if they are inconsistent with what one assumes to be the main purpose of the contract."

64. [1997] SGHC 31, [1997] 1 SLR (R) 277, [26].

65. [2006] 1 SLR 565.

66. Ibid, [32]. 
drawn that the intention was to exclude the operation of the UCP provision in question. In such an event, the express provision will override the provision of the UCP incorporated by reference only."

The court closely followed the Kumagai-Zenecon judgments and held that: ${ }^{67}$

"In the present case, the importance of the price clause and the automatic fluctuation clause to the working of the credit is obvious. Without it, the credit would be unworkable as the price for the gas oil is not fixed but fluctuates with a benchmark. Therefore, even if they were non-documentary conditions, effect should be given to the two express clauses rather than to Art 13(c)."

In the English courts, the disregard rule has never been successfully invoked either. In Credit Agricole Indosuez v Generale Bank (No.2), ${ }^{68}$ the beneficiary contended that the special condition on the latest shipment date was non-documentary, and must therefore be disregarded. Holding that this contention was wholly "misconceived", David Steel J stated that a bill of lading dated after the latest date of shipment would properly be rejected by the bank, and the same would apply to the notice of readiness and the forwarder's receipt. Rather than applying the UCP disregard rule, David Steel J hinted strongly that the bank should not simply disregard a credit term, and it must read the presented documents as a whole. ${ }^{69}$

The second time that the disregard rule failed to be invoked under the English court was in Oliver v Dubai Bank Kenya Ltd. ${ }^{70}$ In this case, condition 3 listed in the standby letter of credit for payment was a confirmation telex issued by the issuing bank to certify the beneficiary's fulfilment of its commitment towards the applicant. The central issue was whether this condition should be disregarded under the UCP 500, Art.13(c) owing to its offence to the principle of independence. Andrew Smith J did not accept that Art.13(c) had any application in this case. In his opinion, ${ }^{71}$

"the express terms of the letter of credit do not make, or purport to make, the obligation to pay conditional upon anything other than a documentary condition. (If they did, then the court might have to consider whether the general words that incorporate the UCP into the letter of credit should prevail over the parties' express stipulation in condition $3 \ldots$ and do so recognising that ... article 1 of the UCP provides that it applies to standby letters of credit "to the extent to which they may be applicable.')"

Although the telex in the present case was a stipulated document by itself, the process of issuing such a document truly depended on the extrinsic events. Andrew

67. Ibid, [33]. One doubt raised by this case was whether the price escalation clause should be regarded as a non-documentary condition at all, although the court did not specifically investigate this issue. It was contended that a price fluctuation clause relating to an amount which could be ascertained from a published survey should not be qualified as a non-documentary condition. See Byrne, supra, fn.46, 651. However, it is noticeable that the bank's access would be denied without subscribing to the relevant webpage, and therefore the information is not available within the bank's operational purview. See Ebenezer Adodo, "Non-documentary Requirements in Letters of Credit Transactions: What Is the Bank's Obligation Today?” [2008] JBL 103, 118.

68. [2000] 1 Lloyd's Rep 123.

69. Although this case was decided under UCP 500, David Steel J did not refer to the linkage test in the Position Paper No.3 to define the non-documentary condition. The same result is likely to be reached under UCP 600 due to the "no conflict" approach added by the ICC Opinion TA.644 rev as ante, text to fn.43. However, the court appeared to have no interest to research the UCP position and instead, it indicated that a condition should only be called non-documentary if its fulfilment cannot be determined from reading the documents into a whole. This implication fits in with the definition in this paper.

70. [2007] EWHC 2165 (Comm).

71. Ibid, [15]. 
Smith J acknowledged that condition 3 imported the bank an implied obligation to issue the telex in some circumstances; however, it would not necessarily conflict with the bank's independent duty to pay under the credit. ${ }^{72}$ Given the consideration of business efficacy, condition 3 was not designed to be a non-documentary condition so as to be disregarded.

The above proves that the conflict between the express terms in the credit and the incorporated UCP provisions has generally been solved by construction of a contract under English law. The general attitude was to give effect to all parts of a contract if possible and no part of a contract should be treated as inoperative or surplus unless there was an irreconcilable inconsistency. ${ }^{73}$ To assess the level of inconsistency, the first step taken by the courts has always been to determine whether a term truly qualified as a non-documentary condition with the ambit of UCP disregard rule. Judging from Credit Agricole Indosuez and Oliver v Dubai, the English courts manifestly incline to interpret the scope of non-documentary conditions narrowly and "documentary proof" has become the key to disqualify a term from being non-documentary, no matter potentially controversial it can be.

Should there be an irreconcilable inconsistency, it is then a question of interpretation whether to give effect to a non-documentary condition of a credit or to the UCP disregard rule. The well-known principle on primacy of designed terms would put the nondocumentary condition in a more privileged position than the disregard rule, to which the UCP has not conferred a paramount status over any inconsistent terms in the credit. ${ }^{74}$ Although there is a general desirability to uphold the UCP regime, it is very difficult to ignore the non-documentary condition which tends to manifest the parties' intention with respect to a particular transaction. It is submitted that the more important a nondocumentary condition affecting the proper working of the credit, the more prepared a court would be to hold that the UCP disregard rule has been implicitly modified or excluded.$^{75}$ As a result, the subsequent action taken by the courts is to call for documentary evidence to enforce the non-documentary condition in the credit. Clearly, the judicial application of the disregard rule under English law has been far more disappointing than the ICC desires to be, and banks would not be able to invoke the UCP disregard rule without a second thought.

72. Clearly, the standby letter of credit in this case was a "suicide credit", as the bank had a sole power to prevent the credit becoming payable. Based on the facts that the bank did not seek to reply upon any claims or defences arisen in the underlying contracts, the English court refused to indorse the argument that condition 3 offended the principle of independence. However, this point might be interpreted differently from the US approach, since condition 3 invites banks to put their determination of payment on extrinsic facts. See James Barnes, "Non-documentary Conditions and the L/C Independence Principle" (2008) 14(4) DCInsight 11.

73. See Pagnan SpA v Tradax Ocean Transportation SA [1987] 2 Lloyd's Rep 342, 349 and Taurus Petroleum Ltd v State Oil Marketing Co of the Ministry of Oil, Republic of Iraq [2017] UKSC 64; [2018] 1 Lloyd's Rep 29, [61] (Lord Sumption). See also Chitty, [13.080] and Lewison, [7.03].

74. It is open to the parties, however, to stipulate that the written conditions are not to override or modify the printed conditions. See Chitty, [13.072].

75. As stated in Rainy Sky SA v Kookmin Bank [2011] UKSC 50; [2012] 1 Lloyd's Rep 34; [2011] 1 WLR 2900, [21] (Lord Clarke): "If there are two possible constructions, the court is entitled to prefer the construction which is consistent with business common sense and to reject the other." This position was recently confirmed in Wood v Capita Insurance Services Ltd [2017] UKSC 24; [2018] Lloyd's Rep Plus 13; [2017] AC 1173, [11] (Lord Hodge). See also Peter Ellinger and Dora Neo, The Law and Practice of Documentary Letters of Credit (Hart, Oxford, 2010) (hereafter "Ellinger"), 239 and Jack, [8.24]. 


\section{FATAL EXCEPTION TO DISREGARD RULE UNDER US LAW}

Differing from most common law jurisdictions, which have no direct legislation on documentary credits, UCC, Art.5, as a part of legal statute, has been compulsorily applied to govern both commercial and standby letters of credit in US jurisdictions. ${ }^{76}$ Due to significant influence achieved by the UCP, UCC Revised Art.5 expressly acknowledges that, when the UCP are incorporated into a letter of credit, the UCP will prevail over UCC Art.5 for any conflicts that have arisen, ${ }^{77}$ apart from the non-variable provisions stated in the UCC Revised Art.5-103(c). ${ }^{78}$ When the UCP or any rules of practice are not incorporated, the UCC Revised Art.5 governs letters of credit in the adopted US states. ${ }^{79}$

UCC Revised Art.5-108(g) ostensibly takes a similar disregard approach to the UCP by stating, "if an undertaking constituting a letter of credit under Section 5-102(a)(10) contains nondocumentary conditions, an issuer shall disregard the nondocumentary conditions and treat them as if they were not stated". ${ }^{80}$ However, through a closer examination, it is not difficult to find that the disregard rule in the UCC is significantly different from the one in the UCP. ${ }^{81}$ According to the Revised Art.5 Official Comments, the disregard rule applies only to a non-documentary condition which does not affect the nature of the instrument as a letter of credit. A non-documentary condition that is central and fundamental to the issuer's obligation is, however, most likely to be accommodated under contract or suretyship law, as its inclusion may remove the undertaking from the scope of Art.5 entirely. ${ }^{82}$

This division is in line with the conclusion of Wichita Eagle ${ }^{83}$ a landmark decision under the UCC 1962 version, in which the court held that a bank's undertaking expressly and conspicuously denominated as a letter of credit was not a documentary credit and was not subject to the law of documentary credit in Art.5. The bank's engagement in this case was to support the performance of a tenant's obligation to construct a parking garage. The bank promised to pay the lessors in the event that the tenant did not exercise diligence in obtaining a building permit and constructing the garage within the time limit. The reason

76. See supra, fn.6.

77. At present, incorporation of UCP will not significantly vary the UCC, since the Revised Art.5 rules have been largely harmonised with the UCP 500 provisions during the drafting process. See Sandra Stern, "Varying Article 5 of the UCC by Agreement" (1997) 114 Banking LJ 516. Note that the UCP 500 disregard rule remains intact in UCP 600.

78. UCC Revised Art.5-116(c). According to UCC Revised Art.5-103(c), apart from the non-variable provisions, Art.5 "may be varied by agreement or by a provision stated or incorporated by reference in an undertaking". The definition of "letter of credit" in UCC Revised Art.5-102(a)(10) is however among the list of non-variable provisions stated in UCC Revised Art.5-103(c), which indicates that the application of Revised Art.5 is restricted to an instrument represented an abstract payment undertaking only.

79. Details of the adopted states can be found at https://www.law.cornell.edu/uniform/ucc\#a5.

80. "Issuer" includes the issuing bank and other non-banking financial institutions who are eligible to issue letters of credit under US law. In this paper, an issuer is assumed to be the issuing bank.

81. One clear difference on the definition of non-documentary conditions has been mentioned. See ante, text to fn.35. More details can be found in Richard F Dole, "The Essence of a Letter of Credit under Revised U.C.C. Article 5: Permissible and Impermissible Nondocumentary Conditions Affecting Honor" (1999) 35 Hous L Rev 1079, 1091-1093.

82. See UCC Revised Art.5-108 Official Comment 9 and Revised Art.5-102 Official Comment 6.

83. Wichita Eagle \& Beacon Publishing Co v Pacific National Bank (1974) 493 F2d 1285 (9th Cir.). 
the Court of Appeal of the Ninth Circuit held that the engagement was a guarantee contract rather than a standby letter of credit was that the bank's promise operated not on the presentation of pieces of paper but instead on factual preconditions to be ascertained. The Court reasoned that this undertaking "strays too far from the basic purpose of letters of credit" and that all distinctions between credits and guarantees would be obliterated if such an undertaking were enforced as a letter of credit. ${ }^{84}$

Clearly, although the Revised Art.5 recognises that certain non-documentary conditions can be included in a letter of credit without denying the status of letter of credit, it does not apply to cases where the non-documentary conditions, "if ignored, leave no obligation to the issuer under the document labelled letter of credit" " ${ }^{85}$ A bifurcated process is therefore developed in dealing with non-documentary issues under US law. The first step is to assess whether the bank's undertaking under such an instrument is truly independent. If it is, and only if it is, the disregard rule would consequently be applied to the instrument representing the independent undertaking.

Two hypothetical examples were given by the Revised Art.5 Official Comments. Under the existing rule, a non-documentary condition in a commercial credit requiring "shipment on vessels no more than 15 years old" would potentially be disregarded under the UCC Revised Art.5-108(g), since it appears to be ancillary to the purpose of the credit on payment for the goods. In comparison, a non-documentary condition in a standby letter of credit stating "payable on the applicant's default in fulfilment of the contractual progress to construct the vessel by 1 June" would most likely run foul of the Wichita Eagle requirement and be enforced as a suretyship condition, because it tends to be central to the bank's undertaking and disregard of it would make the contract worthless.

Nevertheless, it is conceded that the rule does not afford an easy application, as illustrated above, because there is no precise guidance on how to ascertain an independent undertaking in the first place. ${ }^{86}$ The most obvious factor would be to investigate the significance of a non-documentary condition to the operation of a documentary credit transaction. Unsurprisingly, the requirement of judging the importance of a nondocumentary condition goes beyond the capability of an average banker, especially given the short review period in which such a factual determination must be made. The problem therefore goes back to square one, ie, there is no guarantee whether the disregard rule can be successfully invoked against a non-documentary condition until the nature of the bank's undertaking is ascertained by a court or an arbitral tribunal.

It is submitted that the determination of the undertaking must be based on how it would be regarded in commerce rather than the subjective intent of the banks. "What is particularly problematic is that it is often difficult to predict what law a court will apply to one of these borderland instruments-letter of credit law, guaranty law, or a mixture

84. Ibid, 1286.

85. UCC Revised Art.5-102 Official Comment 6.

86. In City of Maple Grove v Marketline Construction Capital (2011) 802 N.W.2d 809 (Minn. Ct. App.), the appellate court noted that general contract principles apply when construing whether an instrument constitutes a letter of credit.

87. See Byrne, supra, fn.46, 650. 
of the two." ${ }^{88}$ For example, in US Acquisition Property XIV LLC v Reserves Development $\mathrm{Co},{ }^{89}$ based on the principle of independence, the court refused to give effect to a nondocumentary condition which stated that, if performance was incomplete by the expiry date, the beneficiary may draw an amount reasonably necessary to complete the project. Comparing this condition with the sampled condition above on "payable on the applicant's default in fulfilment of the contractual progress to construct the vessel by 1 June", how can a bank differentiate between the one that is safe to ignore and the one which is akin to the Wichita restriction and therefore to fall into the fundamental exception?

When a non-documentary condition is regarded to be fundamental, the UCC provides the harshest possible consequence-non-application of the letter of credit law. In this situation, the instrument is probably "some form of suretyship or other contractual arrangement and may be enforceable as such". ${ }^{90}$ The outcome of characterising the instrument as an ordinary contractual obligation undertaken by the bank may raise an ultra vires and unenforceable concern. ${ }^{91}$ Even if the Wichita approach is followed and the instrument can be enforced as a guarantee, it is still counted as "a very drastic solution whose ramifications are different to anticipate", ${ }^{92}$ because turning the bank's undertaking into a "disguised guaranty" 93 would expose the bank into the situation of determining the defaults and liabilities in the underlying contract. A bank that fails to invoke a defence to payment effected in the underlying contract would undoubtedly be faced with the difficulty of getting reimbursement from the applicant.

The above division cannot, however, be curtailed by an express incorporation of the UCP. It is true that in the event of conflicts, UCP would prevail over UCC Revised Art.5 apart from the non-variable provisions stated in Art.5-103(c).$^{94}$ Nevertheless, the nonvariable provisions include the statutory definition of letter of credit and the recognition of the independence principle..$^{95}$ Therefore, when there is a fundamental non-documentary condition threatening the identification of letter of credit as a bank's independent undertaking, the UCC will step in and compulsorily shift the instrument to the category of suretyship or other contractual engagement.

88. Gerald T McLaughlin, "Standby Letters of Credit and Guaranties: An Exercise in Cartography" (1993) Wm \& Mary L Rev 1139, 1139. The difficulty of assessing independent undertakings was also recently experienced by the English courts. See Wuhan Guoyu Logistics Group Co v Emporiki Bank of Greece SA [2012] EWCA Civ 1629; [2014] 1 Lloyd's Rep 266, in which the Court of Appeal reversed the trial court's decision in holding that the undertaking was a guarantee rather than an independent demand bond.

89. (23 Feb 2012) No. S10C-06-034-ESB (Del. Super. Ct).

90. UCC Revised Art.5-102 Official Comment 6.

91. National banks that issue a guarantee may be acting ultra vires under the US Comptroller of the Currency's Regulation 12 CFR 7.7017 (2008), which only permits banks to issue secondary guarantees on limited grounds. However, the courts have generally refused to give banks the benefit of using ultra vires defence and tended to enforce the undertakings. Professor Dole argues that, if the exclusion of the undertaking from Art.5 would render the undertaking unenforceable, courts should not find the condition fundamental and should leave it within the confines of the Art.5. See Dole (1999) 35 Hous L Rev 1079, 1112.

92. Task Force Report, supra, fn.19, 1551.

93. Adam B Strauss, "Disguised Guaranties: Liability for Issuers Ignoring Nondocumentary Conditions in Letters of Credit" (1998) 115 Banking LJ 1039, 1046.

94. See supra, fn.78.

95. See UCC Revised Art.5-102(a)(10), which defines a letter of credit to be "a definite undertaking ... by an issuer to a beneficiary at the request or for the account of an applicant ... to honour a documentary presentation by payment or delivery of an item of value". 
In summary, combination between the disregard rule and the fundamental exception in the UCC imposes a bifurcated process on banks in dealing with non-documentary conditions. The prerequisite is to decide whether the non-documentary condition at issue is central to the operation of the letter of credit, on which consensus is hardly to reach between banks and commercial parties. If a non-documentary condition is fundamental to the operation of the credit, neither the disregard rule in the Revised Art.5-108(g) nor UCP 600, Art.14(h) will apply. At this point, the US approach coincidently leads to the same conclusion, as in the English and Singaporean courts, on the non-application of the disregard rule. ${ }^{96}$ Nevertheless, the attitude in recognising the financial instrument containing non-documentary conditions has been radically different. The US approach tends to seek a more dramatic solution, ie, treating the engagement as a contractual guarantee, while the English approach inclines to maintain the character of independent undertakings and call for documentary evidence to satisfy the condition. ${ }^{97}$ It is clear, though, that, no matter under which regime the parties have chosen to be, the so-called "letter of credit" that contains a non-documentary condition is destined to ride a bumpy road and the application of the disregard rule is not as easy as envisaged.

\section{UNFITNESS OF THE DISREGARD RULE FOR ACHIEVING DESIRED OUTCOMES}

It is claimed that the disregard approach was unanimously chosen by the ICC National Committees in dealing with non-documentary issues because of its "conceptual simplicity and operational ease". ${ }^{98}$ However, as demonstrated earlier, the variable interpretations of the UCP disregard rule and lack of definition on non-documentary conditions have deeply undermined the feature of "conceptual simplicity". Furthermore, with continuous frustration with various judiciary tests, the UCP disregard rule has not truly demonstrated "operational ease" for banks. It is evident that the disregard approach, although wellintentioned, can lead to more serious legal and commercial problems than those it was designed to prevent. ${ }^{99}$

\section{A. Is the disregard rule genuinely fit for the banks' needs?}

First and foremost, it is striking that the legal basis of the UCP disregard rule is unsound. In terms of contractual interpretations, most courts would be very reluctant to prioritise the incorporated UCP provisions and strike out a non-documentary condition which has been specifically drafted in a letter of credit. Moreover, when a bank is trying to invoke

\footnotetext{
96. As discussed, ante, Part III, the UCP disregard rule would be overridden by the non-documentary conditions which are important to the operation of the letter of credit.

97. The tendency of English courts in supporting independent undertakings can be drawn from the earlier Oliver v Dubai Bank of Kenya [2007] EWHC 2165 (Comm) to the recent Wuhan Guoyu Logistics Group Co v Emporiki Bank of Greece SA [2012] EWCA Civ 1629; [2014] 1 Lloyd's Rep 266 and Spliethoff's Bevrachtingskantoor BV v Bank of China [2015] EWHC 999.

98. UCP 500 \& 400 Compared, supra, fn.20, 42.

99. See Goode (1994) 39 St Louis ULJ 725, 736-737.
} 
the disregard provision for its own benefit, it is very likely that the court would adopt the contra proferentem rule to interpret against the UCP provisions, which have been written essentially by banks. ${ }^{100}$ It is further submitted that "a man cannot be permitted to take advantage of his own wrong", ${ }^{101}$ so banks should not be allowed to manipulate the disregard rule and treat as nugatory a condition of their own letter of credit. ${ }^{102}$

Secondly, the inclusion of "fundamental exception" in the UCC Revised Art.5, which aims to strike a balance between following the UCP disregard approach and reflecting the Wichita principle, creates as many questions as it solves for banks. Clearly, Art.5 imposes a legislative command on the banks to ignore non-documentary conditions that are not fundamental but it leaves the document examiners with the task of identifying "fundamental conditions" that they are ill-equipped to handle. ${ }^{103}$ Unsurprisingly, "issuers that fail to anticipate proper application of these rules and statutory or judicially confected exceptions will face an angry beneficiary or an angry applicant with attendant litigation that letter of credit law is supposed to pretermit". ${ }^{104}$

Another problem lies in that, even if a bank is fortunate enough correctly to identify an ancillary non-documentary condition and subsequently disregards it, doubts still exist of the bank's liability towards its applicant under the application contract for issuing a letter of credit, since the bank has specifically agreed to honour the letter of credit on the occurrence of that condition. This form of liability has been hinted in the UCC Revised Art.5 Official Comment, which stipulates "no term in a letter of credit, whether incorporated by reference to practice rules or stated specifically, can free an issuer from a conflicting contractual obligation to its applicant". ${ }^{105}$ An issuing bank may be obliged to disregard a non-documentary condition regarding "shipment on vessels no more than 15 years old" in determining compliance of a presentation under the UCP or UCC rules, but it is likely to generate liability towards the applicant for disregarding this condition, since it has promised the applicant to honour the letter of credit only if all the conditions are satisfied. Although no direct authority can be drawn from the existing case law on this point and the bank's duty of care towards its applicant is far from being settled, ${ }^{106}$ it is at least sensible and logical to say that the courts are inclined to treat applicants gently

100. For example, the court did not allow the non-documentary condition to be disregarded for the issuing bank's benefit in Korea Exchange Bank $v$ Standard Chartered Bank [2006] 1 SLR 565.

101. See Chitty [13.085] and Lewison [7.10].

102. It is argued that even the US courts may be less favourable to invoking the Wichita rule when it is the issuing bank who benefits from a holding that the undertaking is not a letter of credit. See Bouzo v Citibank NA (1996) 96 F3d 51 (2d Cir.); Teleport Communications Group Inc v Barclay Financial Group Ltd (1999) 176 F 3d 412 (7th Cir.) and Dolan, [2.05[2][c]].

103. See Dolan, [2.05[2][f]]. It is suggested that, comparing with commercial credits, banks are less familiar with the conditions in standby credits. Therefore, the problem of distinguishing fundamental conditions is even more prevalent in standby cases.

104. Ibid.

105. UCC Revised Art.5-103 Official Comment 2. See also the UCC Revised Art.5-108 Official Comment 9. The same concern is shared by Jack, [8.26].

106. The majority hold the view that banks owe their customers/applicants a duty to warn that the stipulated condition will be of no effect: see eg Jack, [8.23] and Roy Goode, "Abstract Payment Undertakings in International Transactions" (1996) 22 Brook J of International Law 1, 12. However, since this involves extending banks' responsibility and making them scapegoat, it is disapproved by Adodo [2008] JBL 103, 119. 
when the interests of applicants unexpectedly run foul of a rule proposed by banks that favours themselves. ${ }^{107}$

Therefore, although the disregard rule may on first impression appear to be a straightforward approach for banks, it cannot offer a unified solution to deal with all sorts of non-documentary conditions, nor be regarded as a safe approach in the legal sense. It is evident that problems raised by the disregard approach are more than peripheral difficulties; they penetrate into the heart of legal sustainability.

\section{B. Incompatible tension against commercial expectations}

It has been suggested that the UCP are essentially written for banks to assist their dayto-day practice. Nevertheless, no banks would like to see their customers turning away from using letters of credit owing to frustrations and disadvantages placed by the banking rules. The disregard approach and its existing application lead to precisely this danger. Without doubt, an applicant asks the bank to issue an independent undertaking with the non-documentary condition presumably because the condition is important and he expects it to be enforced. By permitting the bank to ignore that condition afterwards, the disregard rule thwarts the applicant's reasonable expectations. On the other hand, when a non-documentary condition plays a fundamentally important role in the letter of credit, the court will find a way to enforce it, whether as a matter of letter of credit law or as a matter of some other body of law. Such enforcement will surely leave the beneficiary, who has put his faith in the disregard rule in a difficult situation, especially when he realises that the so called "letter of credit" does not even represent a bank's independent undertaking and is subject to all the defences under a contractual guarantee. ${ }^{108}$

The conflict between the existing regime, dominated by the disregard approach, and the commercial parties' expectations appears to be even more acute in the case of standby letter of credit, which currently hold twenty times more trade volume than commercial letters of credit in the US. ${ }^{109}$ It is acknowledged that, although both commercial and standby letters of credit represent bank's independent undertakings and are documentary in character, they are functionally different. A commercial credit responds to the applicant's primary obligation to pay for the goods, while a standby credit aims to guarantee the applicant's performance in the underlying contract and payment is designed to compensate the applicant's default. It is fair to say that payment undertakings under standby credits, though primary in form, are secondary in intent. ${ }^{110}$ If the bank ignores a non-documentary

107. See John F Dolan, "Letters of Credit: A Comparison of UCP 500 and the New U.S. Article 5" [1999] JBL 521, which also suggests that it is banks that should take the responsibility for issuance of non-documentary conditions, not their customers, as banks are in the best position to avoid such conditions in the first place.

108. Under a conditional guarantee, the beneficiary who claims payment from the guarantor would be subject to the same defences and the set-off rights available to the principal debtor in the underlying contract, as the guarantor is able to step into the shoes of the principal debtor.

109. Within totals for letter of credit activities in the first quarter of 2018, outstanding standby obligations stood at US\$365.94 billion and commercial letters of credit were US\$16.06 billion. See quarterly figures reported in Statistics: US Banks, supra, fn.1. There are on-going discussions regarding removing standby letters of credit from the scope of application of the UCP. However, this possibility cannot solve the current dilemma created by non-documentary conditions, since the disregard approach has been copied into various international rules on standby letters of credit.

110. Goode (1994) 39 St Louis ULJ 725, 730. 
condition which requires the beneficiary to establish the applicant's default in a poorly drafted standby credit, the distortion to the applicant's commercial expectation may be egregious, as the non-documentary condition is vital to control the payment and without it the standby credit will be equal to a blank cheque. ${ }^{111}$

On the other hand, standbys are more likely to raise questions whether the bank's undertaking is intended to be and should be interpreted as independent. Payment under a standby credit is triggered by defaults which are generally central to the underlying agreement but ostensibly represented in the documents. Without specifying the documents to evidence the defaults, the theoretical distinction between accessory guarantees and standby credits would disappear, and the court may well refuse to apply abstract obligation law to an undertaking containing vague conditions. ${ }^{112}$ Consequently, the beneficiary, whose deal would be mysteriously turned from a "beneficiary oriented" independent undertaking to an "applicant oriented" conditional guarantee, and he must prove the actual occurrence of a default as well as conquer the challenging defences raised from the underlying contract. ${ }^{113}$ Clearly, this outcome is far beyond the beneficiary's normal expectation in requesting an instrument representing the bank's independent payment undertakings.

In conclusion, the cure provided by the disregard rule in the process of document examination may prove worse than the disease. Although the disregard approach is adopted essentially for banks, it fails to provide or even consider the subsequent legal consequences faced by unwary banks. More importantly, the current regime generated by the disregard approach runs foul of the reasonable expectations of commercial parties, which will inevitably lead to undermining confidence in the use of letters of credit. It is fair to say that, in effect, the UCP penalise commercial parties when banks misbehave by issuing or confirming a poorly drafted credit. The express structure of UCP allows "less well counselled banks to foist the cost of their misjudgements onto the commercial parties" by ordering banks to ignore the non-documentary conditions created by themselves. ${ }^{114}$

\section{POSSIBILITY OF AN ALTERNATIVE APPROACH: CONVERT TO PAPER?}

It is obvious now that the disregard rule under the existing regime regrettably cannot achieve the results desired. This paper therefore proposes, next, to reconsider the feasibility of an alternative approach, ie, the "calling for evidence approach", which was historically considered as the second preferable choice on the list for treatment of nondocumentary conditions, by both the UCC Task Force and the UCP 600 drafting group. ${ }^{115}$ Prior to the disregard approach's being officially recognised in the UCP and echoed

111. Dolan [1999] JBL 521, 534.

112. For example, the UCC recognises such a conditional undertaking as a form of suretyship and expressly removes it from the scope of Art.5. See UCC Revised Art.5-102 Official Comment 6 and Art.5-103 Official Comment 1.

113. McLaughlin (1993) Wm \& Mary L Rev 1139, 1139.

114. John F Dolan, "Weakening the Letter of Credit Product: The New Uniform Customs and Practice for Documentary Credits" [1994] 2 IBLJ 149, 162.

115. See the Task Force Report, supra, fn.19, 1550 and Gary Collyer, "A Look Back at the UCP Revision" (2006) 12(4) DCInsight 1, 23. 
in other major rules, some banks had been converting non-documentary conditions into documentary conditions by requiring the production of a document to evidence fulfilment of the stated condition. As this sensible approach could well maintain the independent character of letters of credit, it has been generally supported by the courts, especially in England. ${ }^{116}$

The landmark case concerning this approach in the English courts was Banque de l'Indochine et de Suez SA v JH Rayner (Mincing Lane) Ltd. ${ }^{117}$ In this case, one of the conditions in the credit stipulated "Shipment to be effected on vessel belonging to Shipping Company that is a member of an International Shipping Conference"; however, the credit did not call for a shipping company certificate to evidence its fulfilment. The confirming bank refused to pay the beneficiary in the absence of documentary proof of this non-documentary condition. Parker J held that: ${ }^{118}$

"since the credit expressly stipulated for shipment on what for convenience I shall call merely "a Conference Line vessel", the plaintiffs [confirming banks] were both entitled and obliged to ensure that the stipulation was complied with. No specific documentary proof was called for by the credit but, since parties to documentary credits deal only in documents, the bank were in my judgment entitled to insist upon, and the defendants [beneficiaries] were obliged to provide, reasonable documentary proof. The requirement for a certificate was, in my view, a reasonable requirement and accordingly the bank were entitled to regard its absence as a valid ground for refusing payment even if, as was in fact the case, the vessel was a Conference Line vessel."

In the Court of Appeal, Sir John Donaldson MR fully upheld Parker J's decision and added: ${ }^{119}$

"The condition required a state of fact to exist. What the letter of credit should have done was to call for a specific document which was acceptable to the buyer and his bank evidencing the fact that the vessel was owned by a member of a conference. It did not do so and as, accordingly, the confirming bank had to be satisfied of the fact, it was entitled to call for any evidence establishing that fact."

The evidence approach established by the Rayner case was followed by later cases. In Floating Dock Ltd v Hong Kong \& Shanghai Banking Corp,${ }^{120}$ Evans J held that the bank was entitled to demand any documentary evidence to satisfy the condition on "latest delivery date" stipulated in the credit. In The Messiniaki Tolmi ${ }^{121}$ concerning the condition of "a Gas-free certificate to be approved by the Taiwan Authorities" in the credit, the Court of Appeal held that the approval had to be evidenced by a contemporary document accompanying the gas-free certificate or by endorsement on the certificate itself. Lloyd LJ emphasised that "the fact that such documentary evidence may have

116. For the US, see Universal Savings Association v Killeen Savings \& Loan Association (1998) 757 SW 2d 72 (Tex Ct App), which contended that the bank should accept documentary proof of the non-documentary conditions.

117. [1982] 2 Lloyd's Rep 476; [1983] QB 711. The letter of credit in this case was subject to UCP 1974 revision, where had no express provision concerning non-documentary conditions.

118. [1982] 2 Lloyd's Rep 476, 480; [1983] QB 711, 719.

119. [1983] 1 Lloyd's Rep 228, 230-231; [1983] QB 711, 728.

120. [1986] 1 Lloyd's Rep 65, 79-80. The non-documentary requirement in the credit was stating that "the latest delivery date is 20 February 1985 ".

121. Astro Exito Navegacion SA v Chase Manhattan Bank NA (The Messiniaki Tolmi) [1986] 1 Lloyd's Rep 455 (QB); affd [1988] 2 Lloyd's Rep 217 (CA). 
been hard or even impossible to get is neither here nor there". ${ }^{122}$ Moreover, the approach that has continued to be used in post-UCP 500 cases when the UCP disregard rule is overridden by the inclusion of a fundamental non-documentary condition. ${ }^{123}$

The English courts generally recognise that conditions in letters of credit are intended to be documentary in character, such that a non-documentary condition referring to external facts would be treated as a requirement to produce reasonable documentary evidence of that effect. What the bank is going to examine is the documents representing the facts rather than the other way around. The evidence approach maintains the independence of the bank's undertaking and makes the letter of credit operate on a representational level. Moreover, compared with the disregard rule and its draconian fundamental exception, the evidence approach is a better fit for the commercial parties' expectations, because it would fulfil the applicant's request on the non-documentary condition and preserve the integrity of a bank's independent payment undertaking at the same time.

The major reason for the banking community's resisting the evidence approach is that "this approach, however, places all risks on the issuer to determine the required form and substance of any such document". ${ }^{124}$ There are massive concerns that the bank's discretion on reasonable documentary proof could be different from the applicant's anticipation, so as to jeopardise the bank's chance of getting reimbursement from the applicant. Nevertheless, as discussed above, the problematic application of the disregard rule does not leave the banks in peace. The banks still need to assess the importance of a non-documentary condition and face potential liabilities towards the applicants. Compared with the task of categorising non-documentary conditions which the banks are ill-equipped to handle, asking for documentary evidence and judging whether such documentary proof can satisfy the credit condition are within their expertise.

It has also been argued that "the evidence approach makes sense in the Rayner context, but would not make sense in many standby situations, where the transactions are so often unique and where document examiners would be hard put to know which documents satisfy the nondocumentary condition". ${ }^{125}$ The statement appears to be true to some extent; however, the problem is not without a solution. As stipulated in the UCP, when a credit requires presentation of a document without stipulating its data content, "banks will accept the document as presented if its content appears to fulfil the function of the required document". ${ }^{126}$ If we apply the analogous standard to the current context, banks are entitled to accept any documentary evidence as presented if its content appears to fulfil the non-documentary condition stipulated in the credit. In addition, as is the case with the other presented documents in the letter of credit, a bank is not responsible for genuineness, sufficiency or materiality of the document proof. ${ }^{127}$

122. Ibid, 220.

123. The Singaporean courts eventually called for documentary proof to enforce the fundamental nondocumentary conditions in both Kumagai-Zenecon Construction Pte Ltd v Arab Bank Plc [1997] 3 SLR 770 and Korea Exchange Bank v Standard Chartered Bank [2006] 1 SLR 565. See ante, text to fnn 62-67.

124. Janis P Soshuk, "The Consequences of Nondocumentary Conditions" (1990) 56 Brook L Rev 33, 41.

125. Dolan, [6.04[7]].

126. UCP 600, Art.14(f).

127. In Gian Singh \& Co Ltd v Banque de l'Indochine [1974] 2 Lloyd's Rep 1; [1974] 1 WLR 1234, the Privy Council held that the bank's ability to claim a complying presentation would not be affected by the fake passport 
One might argue that the above method of assessing the sufficiency of documentary proof would give banks too much discretion, so as to cause uncertainties and unfairness to commercial parties. ${ }^{128}$ However, it must be admitted that the bank's discretion is voluntarily granted by the parties, who have neither stipulated a corresponding document nor specified the data content to satisfy the non-documentary condition. When the applicant's mandate is ambiguous, it is well established that the bank is entitled to rely upon any reasonable interpretation of an ambiguous expression. ${ }^{129}$ The evidence approach manifestly reallocates the risk undertaken by the commercial parties caused by the inclusion of a non-documentary condition in the credit. The applicant will obtain some form of documentary evidence from the bank, which may not be as satisfactory as he desires, for the fulfilment of non-documentary conditions, but his position is better than getting nothing under the disregard rule. The beneficiary, on the other hand, needs to provide reasonable documentary evidence to prove the satisfaction of the non-documentary condition, but he can actually avoid the risk of facing different judicial interpretations on enforcing fundamental non-documentary conditions.

Lastly, it has been contended that the burden of a non-documentary condition must be placed on the applicant and the issuing bank to issue the credit properly, rather than shifting it to other parties. ${ }^{130}$ Based on this rationale, one can infer that the working order of the disregard rule should always favour the beneficiary and possibly the nominated banks. When the disregard rule works against the beneficiary or possibly the nominated banks, like in Korea Exchange Bank $v$ Standard Chartered Bank, ${ }^{131}$ it will be set aside. ${ }^{132}$ This rationale is understandable but the supremacy conferred on the beneficiary and nominated banks is far from being justifiable. It has to be remembered that the beneficiary has every chance to examine the letter of credit before it is established and to raise objections against any condition that is suspicious. If a letter of credit is not issued in line with the requirements under the underlying contract, he is entitled to request credit modification through the applicant, or he may even have a right to suspend performance under his underlying contract. ${ }^{133}$ By the same token, a letter of credit infected with a non-documentary condition will not come into being if a bank, in advising, confirming or negotiating the credit, acts with reasonable expertise. ${ }^{134}$

which appeared to satisfy the requirement of the signature on the certificate. UCP 600, Art.34 also contains a disclaimer to the bank's responsibility.

128. See Ellinger, 238-239.

129. See Commercial Banking Co of Sydney Ltd v Jalsard Pty Ltd [1973] AC 279; [1972] 2 Lloyd's Rep 529. The latest ISBP 745, [v] states: "The applicant bears the risk of any ambiguity in its instructions to issue or amend a credit. An issuing bank may, unless the applicant expressly instructs to the contrary, supplement or develop those instructions in a manner necessary or desirable to permit the use of the credit or any amendment thereto." The same contra proferentem approach must apply against the issuing bank when the issuing bank gives unclear instructions to its nominated banks and the beneficiary. See BasicNet SpA v CFP Services Ltd (2014) 120 AD 3d 97; 988 NYS 2d 593 (N.Y. App. Div.).

130. See UCP 500 \& 400 Compared, supra, fn.20, 43.

131. [2006] 1 SLR 565 (supra, fn.65).

132. In Korea Exchange Bank [2006] 1 SLR 565, [29], Andrew Ang J held that the UCP disregard rule avails the negotiating bank or confirming bank against the issuing bank and, arguably, the issuing bank against the applicant, but not the other way round.

133. See Glencore Grain Rotterdam BV v Lebanese Organisation for International Commerce [1997] 2 Lloyd's Rep 386. Similar rights can be found in the UCC Art.2-325(1).

134. Adodo [2008] JBL 103, 119. 
Hence, no one involved in a letter of credit containing non-documentary conditions can evade its own responsibility and, likewise, all the parties have to share the potential risk brought by such conditions.

In summary, the calling for evidence approach adopted by the English courts turns the non-documentary conditions into an examination of documentary proof that represents the occurrence or non-occurrence of that event. This legally sound approach permits banks to enforce the non-documentary condition in a manner which complies to the maximum extent with the reasonable expectations of the commercial parties. In the author's view, the calling for evidence approach fairly distributes the risk taken by all the parties involved without sacrificing the efficiency of documentary credit as an autonomous payment system. It is conceded that this is not a perfect approach without any contentions but, at least for now, these contentions could be settled by appropriate and careful adjustments to the approach.

\section{CONCLUSIONS}

This paper argues that the UCP disregard rule is not an effective and sensible approach to the existence of non-documentary conditions in a letter of credit-not least, because courts would not ignore a term which has been expressly drafted by the parties. The UCP disregard rule appears to offer the banks a simple solution to neglect non-documentary conditions. However, as discussed, this solution is merely a paper shield for unwary banks. When we pay close attention to the UCP disregard rule itself, it turns out that neither a clear interpretation nor an overriding status for the application of the disregard rule is provided by the UCP.

The noticeable outcome of this failure leads to diverse recognition on what is a nondocumentary condition and different judicial interpretations of the application of the disregard rule. The courts led by English law tend to follow the rules of construction and manifest the parties' intention behind non-documentary conditions to the best degree. In comparison, the US jurisdiction follows the established "fundamental exception" to exclude the application of the disregard rule and treats the so-called "letter of credit" as a disguised guarantee with the governance of suretyship law. The distinction between a fundamental and non-fundamental non-documentary condition is well beyond the bank's realm. Without such knowledge, the bank would not be able to navigate itself safely under the existing regime dominated by the disregard approach.

It is regrettable to see that the UCP disregard rule combined with the fundamental exception not only fails to achieve the desired simplicity or place banks beyond legal reproach, but also frustrates the commercial parties' business expectations and deters the previous effective practice of calling for evidence. By applying the disregard approach, an applicant's honest belief on satisfaction of express credit terms will be unfairly unfulfilled. On the contrary, when a non-documentary condition triggers the fundamental exception, the beneficiary might be left in an astonishing position, as his bargain could be mysteriously changed from an independent undertaking to a conditional guarantee. 
It is unwise simply to disregard the non-documentary conditions in a letter of credit, as well as ignore the complexities and uncertainties triggered by the existing regime. What both the commercial parties and the banks need is merely a piece of paper to convert the non-documentary conditions so as to maintain the bank's integrity. This paper therefore proposes that the calling for evidence approach taken by the English common law can well satisfy this need, as the essence of this approach is to turn a non-documentary condition into documentary proof representing the occurrence or non-occurrence of the fact. However, in terms of risk allocation, the bank and the applicant have to make a compromise to accept any documentary evidence provided by the beneficiary as long as it can fulfil the function of proof. Without doubt, the only way to avoid any potential risk is not to issue, confirm or advise a letter of credit containing non-documentary conditions. 